\title{
PENGEMBANGAN MANAJEMEN KELAS OLAHRAGA: POKOK-POKOK PIKIRAN TENTANG PENGEMBANGAN PEMBINAAN OLAHRAGA BAGI PELAJAR
}

\author{
Agus Mahendra \\ Prodi PGSD PENJAS Departemen Pendidikan Olahraga \\ Fakultas Pendidikan Olahraga dan Kesehatan \\ Universitas Pendidikan Indonesia, Jln. Setiabudhi No. 229 Bandung \\ Agus_mahendra@upi.edu
}

\begin{abstract}
Abstrak
Naskah ini merupakan pemikiran ringan terkait dengan upaya melahirkan gagasan tentang benang merah pembinaan olahraga di Indonesia yang masih sering bersifat potong kompas dan yang paling kentara adalah tidak sambungnya antara sub-sistem pembinaan yang satu dengan subpembinaan yang lain. Satu hal yang sering terlupakan oleh umumnya pembina dan praktisi adalah betapa tidak pernah diakomodasinya sub-sistem pembinaan di sekolah, karena belum diperhatikannya baik eksistensi sekolah dan berbagai pramarta-nya maupun potensi SDM yang tersedia di dalamnya. Pembinaan olahraga di sekolah selama ini malah tidak dibeli alur khusus karena para siswa yang berbakat olahraga seolah cerabut dari dunia sekolah dan dibina khusus di luar sekolah, sehingga tidak mendukung atmosfir sekolah sebagai pusat pembinaan. Naskah ini mencoba mengingatkan kita semua tentang pentingnya sekolah diberi peluang peran untuk mengembangkan pembinaan olahraga terutama dalam bentuk "kelas olahraga" dan bagaimana hal itu dikelola secara memadai.
\end{abstract}

Kata kunci: pembinaan olahraga, kelas olahraga, olahraga sekolah

\section{PENDAHULUAN}

Pembinaan olahraga terhadap anak-anak dan remaja berbakat perlu dilakukan secara berjenjang dan berkelanjutan. Untuk itu, alangkah perlunya mengangkat pemikiran agar sekolah menjadi salah satu tempat pembinaan yang strategis, karena sekolah merupakan tempat berkumpulnya anak-anak dan remaja yang terorganisir. Di samping itu, setiap sekolah pasti memiliki guru Penjas yang jika diberdayakan, memungkinkan proses bimbingan dan latihan lebih bermakna karena mereka selain merupakan ahli di bidang keolahragaan, mereka juga merupakan para pendidik yang profesional dalam pembentukkan kepribadian anak secara utuh.

Sampai saat ini pembinaan olahraga prestasi bagi siswa/siswi berbakat yang merupakan cikal bakal atlet berprestasi belum menunjukkan kesinambungan yang terintegrasi dengan sistem pembinaan atlet berprestasi. Pada umumnya mereka datang dan di bina di klub-klub olahraga yang ada di masyarakat, yang secara struktural berada di bawah top-top organisasi olahraga prestasi. Kondisi demikian kurang mengakomodasi jumlah siswa berbakat yang sebenarnya tersebar di seluruh sekolah, karena : (1) baik secara kecabangan maupun jumlah klub yang sejenis di setiap kabupaten atau kota relatif 
terbatas, (2) akibat keterbatasan jumlah klub secara geografis hanya sedikit siswa berbakat yang dapat mengakses secara mudah ke klub, (3) keterbatasan kemampuan klub-klub untuk memenuhi kebutuhan atlit berbakat baik karena masih bervariasinya kemampuan profesional pembina atau pelatih maupun variasi kepemilikan alat dan sarana latihan, dan (4) sering terjadinya benturan kepentingan antara kepentingan belajar di sekolah dengan kepentingan berlatih atau bertanding di klub.

Pengakomodasian pembinaan olahraga prestasi bagi siswa-siswa yang berbakat di sekolah umunya masih dilaksanakan dalam tataran kegiatan ekstra kurikuler. Akibatnya, pelaksanaannya masih ditujukan untuk kepentingan pendidikan, sementara kepentingan prestasi olahraga secara khusus belum tergali secara optimal. Hal ini salah satunya terkait dengan realisasi pendanaan untuk kegiatan tersebut, di mana kegiatan ekstra kurikuler sebagai salah satu kegiatan belajar formal yang tentunya alokasi pendanaannya didapat dari departemen pendidikan nasional juga masih terbatas. Sementara ini, untuk pembinaan prestasi yang sebenarnya berhubungan erat dengan kepentingan prestise daerah belum didukung secara layak oleh pemerintah daerah.

Jika pemerintah dan masyarakat sepakat bahwa salah satu indikator keberhasilan pembangunan olahraga adalah prestasi yang diperoleh pada PON dan mendukung terhadap pembinaan prestasi nasional, dan sekolah dianggap sebagai basis potensial pembinaan cikal bakal atlit berprestasi, maka sangatlah wajar jika pemerintah pusat dan daerah, dinas pendidikan, dan sekolah bahu membahu menfasilitasi sumber-sumber pendukung yang dapat mengekspresikan seluruh potensi siswa berbakat secara optimal.

\section{PEMBENTUKAN SEKOLAH BERBASIS KELAS OLAHRAGA}

Meskipun saat ini kemampuan pemerintah dan masyarakat dalam kondisi serba keterbatasan, namun perlu diupayakan cara-cara yang dianggap masih wajar untuk menfasilitasi siswa-siswa berbakat untuk mengekspresikan keberbakatannya. Salah satu upaya yang diduga dapat diterapkan adalah pengembangan model Kelas Olahraga. Komponen utama dari model ini adalah (1) pemberdayaan sekolah sebagai sentra pembinaan olahraga prestasi yang terintegrasi dengan pelayanan kependidikan lainnya, (2) pemberdayaan masyarakat pendidikan, masyarakat olahraga, dan pemerintah daerah, untuk bersama-sama mewujudkan satu sentra pembinaan olahraga yang terintegrasi dengan layanan kependidikan dalam satu wadah sekolah, di mana para siswa berbakat digabungkan dalam satu atau beberapa kelas yang disebut kelas olahraga.

Dikaitkan dengan kepentingan sistem keolahragaan nasional (SKN), banyaknya potensi atlet berprestasi dari kalangan pelajar dan lahirnya kebijakan Kelas Olahraga ini merupakan langkah awal dan modal dasar untuk membuka sebuah jalur khusus, yang dapat dipandang sebagai suatu sub-sistem keolahragaan nasional. Oleh sebab itu, perwujudannya perlu direncanakan secara strategis melalui usaha-usaha pengkajian yang tepat.

Dari sisi pengertian, Kelas Olahraga adalah sebuah model pembinaan yang dilaksanakan di sekolah target yang melibatkan sekelompok siswa yang teridentifikasi "berbakat" olahraga (memiliki keunggulan olahraga) dalam lingkup sekolah. Dengan model ini, tugas siswa dari anggota Kelas Olahraga yang paling utama adalah mengikuti proses pembinaan olahraga, tetapi dengan tidak meninggalkan kewajiban mereka dalam bidang akademiknya.

Model ini diharapkan dapat menjadi salah satu alternatif model pembinaan di luar jalur klub olahraga yang sudah ada, yang pengelolaannya biasanya ada di bawah pengelolaan Pengcab dan KONI kota.

Dengan demikian, model Kelas Olahraga akan berada di bawah pengelolaan manajemen sekolah, yang secara umum bertanggung jawab dari sisi perekrutan peserta 
didik (seleksi keberbakatannya), program pelatihan, penyediaan pelatih dan sarana serta prasarana yang memadai.

\section{PENETAPAN RENCANA STRATEGIS KELAS OLAHRAGA \\ Standard Sarana dan Prasarana}

Dari sisi sarana dan prasarana, Kelas Olahraga diharapkan memiliki stndard minimal yang menyamai standard yang baik, minimal untuk satu atau beberapa cabang olahraga. Oleh karena itu, secara bertahap, sarana dan prasarana keolahragaan di sekolah yang bersangkutan dapat terus ditingkatkan serta dipertahankan kualitasnya, syukur-syukur jika mendapat dukungan dari APBD melalui Dinas Pendidikan Provinsi atau minimal Kota/Kabupaten, yang secara progresif tentu harus ditingkatkan.

Dilihat dari kondisi umumnya sekolah saat ini, termasuk untuk sekolah-sekolah di kota besar, rasanya sulit untuk menilai bahwa sekolah tertentu sudah memiliki fasilitas olahraga yang memenuhi standard. Apalagi Kelas Olahraga ini menetapkan bahwa olahraga wajibnya adalah Atletik. Oleh karena itu, sebaiknya sekolah yang bersangkutan, mencoba memanfaatkan fasilitas yang dimiliki oleh pihak lain, atau memanfaatkan fasilitas milik Pemda.

\section{Sistem Rekrutmen Calon Siswa}

Perekrutan calon siswa bagi Kelas Olahraga ini, tentunya didasarkan pada satu sistem yang mengakui kesatuan utuh calon siswa yang memiliki potensi secara nyata dalam berbagai aspek seperti aspek fisik, aspek mental, serta aspek moral dan emosional. Oleh karena itu, perekrutannya didasarkan pada seperangkat tes yang dapat mengukur kualitas fisik dan motoriknya, yang mengukur keunggulan dan kualitas mental-emosional, serta sekaligus mengukur aspek kepribadian serta potensi moralnya.

Hal ini dipandang penting, karena atlet olahraga yang unggul, seharusnya memiliki kesemua kualitas tersebut, agar tidak drop-out dan menimbulkan masalah dalam perjalanan prosesnya, termasuk menjadi beban berat bagi pengembangan di masa-masa mendatang.

Secara fisik, perekrutan atlet ini diawali dari pengukuran anthropometrik yang lengkap, dan hasilnya dibandingkan secara khusus dengan parameter anthropometrik modern dari setiap cabor yang relevan. Demikian juga dengan status kesehatan atlet, yang harus diperiksa seksama meliputi penelusuran dan anamnesa cermat hingga riwayat kesehatan si atlet dan keluarganya. Meskipun si atlet dianggap telah berprestasi baik dalam cabang yang ditekuninya, tetapi jika secara anthropometris dan riwayat kesehatan dan berbagai kualitas dasar fungsi organ-organ tubuhnya tidak memenuhi syarat, si atlet tidak punya harapan untuk diterima dalam program ini.

Dilihat dari kondisi fisik, si atlet harus mengikuti serangkaian tes kebugaran jasmani dan tes kemampuan motorik (motor abilities) secara lengkap, sehingga akan tergambar potensi fisik dan motoriknya secara komprehensif. Tes semacam sport search yang dikembangkan di Australia, mungkin merupakan keharusan awal, syukur-syukur tes inipun dapat langsung menggunakan tes keberbakatan cabang olahraga yang sudah dikembangkan oleh masing-masing cabor di tingkat dunianya.

Dari sisi psikologis dan mental, atlet perlu dijaring melalui tes yang berkaitan dengan kemampuan psikologis dan mentalnya dalam menghadapi beban latihan yang berat. Serangkaian tes psikologis yang bersifat praktek perlu diberikan kepada setiap calon, untuk melihat ketahanan mental dan psikologisnya yang berkaitan dengan kecemasan (anxiety), kestabilan (steadiness), keberanian (courage), kesiapan (readiness), dan kemarahan (anger). Kualitas emosional yang tergambar, akan menetapkan bahwa atlet memiliki kualitas atlet yang berdaya juang tinggi serta memiliki kemampuan fokus pada tujuan yang telah ditetapkan.

\section{Standard Minimal Pelayanan dan Proses Pembinaan}


Proses pembinaan yang dilaksanakan di Sekolah Berbasis Olahraga adalah proses pembinaan lengkap yang dirancang melalui program latihan terpadu dengan penggunaan simulasi musim pertandingan utuh. Atlet sebagai peserta didik akan mengikuti program latihan tersebut secara teratur, dari mulai tahap Persiapan Umum, tahap Persiapan Khusus, serta Tahap atau Musim Pertandingan, dan diakhiri oleh Tahap Pascapertandingan. Proses pembinaan berlangsung sebagai sebuah siklus besar yang berulang pada setiap tahunnya, serta disesuaikan secara apik jika dihadapkan pada pertandingan yang sesungguhnya.

Proses ini dilaksanakan secara serius, sehingga tergambar juga dalam beban-beban latihan dari setiap mikro-siklusnya (microcycle), yang mengharuskan atlet berlatih pada setiap harinya minimal dua sesi latihan, yaitu pagi dan sore dengan frequensi 4 sampai dengan 5 hari dalam seminggu.

Pelayanan dukungan dalam proses pelatihan ini idealnya meliputi layanan akomodasi yang memadai, layanan konsumsi dengan menu yang disusun oleh ahli gizi, layanan kesehatan dan perawatan cedera dari para dokter spesialis dan ahli terapi, serta layanan akademik yang fleksibel tetapi terstandarisasi, sehingga proses pembelajaran memungkinkan dilaksanakan oleh setiap atlet secara individual maupun kelompok. Yang juga tidak boleh dilupakan adalah adanya tim psikolog yang juga bertugas memberikan layanan konsultasi psikologis bagi atlet yang terlanda permasalahan psikologis, baik yang berkaitan dengan persoalan pribadi, karir keatletannya, maupun persoalan-persoalan lain yang dipandang menghambat proses belajar dan pelatihan.

Masih dari sisi psikologis, perlu juga latihan disandingkan dengan latihan mental (mental practice) yang rutin, sehingga pada saat yang bersamaan para atlet memiliki ketangguhan mental dan positive thinking yang baik, di samping membantu penguasaan keterampilan gerak dan kestabilan emosi melalui program latihan nir-gerak.
Bahkan, jika memungkinkan, kondisi mood para atlet pun dapat dipantau secara rutin, sehingga para pelatih mengetahui cara-cara penanggulangannya secara sederhana. Latihan ynag intensif, tentu akan memberikan stress yang tinggi bagi kondisi mental atlet; termasuk pada mood atlet yang berkaitan dengan kesiapan (alertness), kebosanan (boredom), kemarahan (anger), kecemasan (anxiety) serta keriangan (cheerfulness). Beberapa instrument mood inventory sebenarnya tersedia, dan praktek pengukurannya dapat dilakukan oleh atlet sendiri, untuk diinterpretasikan hasilnya oleh para pelatih.

\section{Model Implementasi Kelas Olahraga}

Untuk memperkuat proses pembinaan yang berlangsung ketat dan seolah berorientasi pada prestasi pribadi masing-masing atlet, proses kependidikan secara keseluruhan dirancang dengan program yang mampu mengkompensasi keterlibatan dan interaksi peserta didik dengan kelompok atau teman sebayanya. Dari sisi pendidikan jasmani (intrakurikuler) misalnya, digunakan model-model kurikulum Sport Education, yang lebih menekankan kepada tumbuhnya pengalaman bersama dengan siswa lain untuk membangun sebuah komunitas insan olahraga sebagai pembelajaran keterampilan sosial. Kepada anak diperkenalkan berbagai peranan yang harus dijalani, tidak hanya sebagai atlet, tetapi semua siswa merasakan peranan seperti pelatih, wasit, manajer, penonton, bahkan reporter yang sering hadir dalam setting kompetisi olahraga. Dengan model seperti ini, semua siswa dari berbagai cabor yang berbeda, pada saat-saat pembelajaran di kelas, bisa berinteraksi langsung dan saling mengenal satusama lain.

Ini dipandang penting, mengingat selama ini, akibat jadwal latihan dan kejuaraan yang ketat, para atlet cenderung 'memisahkan diri' secara ekslusif, dan hanya bergaul dengan atlet lain dari cabang olahraga yang sama. Hal ini kurang baik dari sisi kependidikan, sehingga dipandang penting, menterjadikan mereka bergaul secara luas dengan sesama teman satu sekolah 
meskipun berasal dari cabang olahraga yang berbeda.

\section{Rekrutmen Ketenagaan}

Satu faktor penting yang tidak boleh dilupakan oleh kita semua bahwa Kelas Olahraga perlu didukung oleh barisan SDM pendidik yang unggul pula. Membina orangorang unggul memang harus dilakukan oleh orang-orang yang unggul pula, baik dari sisi kepemimpinan, keahlian substantial, hingga keunggulan komitmen dan pengabdiannya. Oleh karena itu dapat disimpulkan bahwa para guru dan pelatih yang direkrut untuk bertugas di Sekolah ini adalah orang-orang pilihan yang siap menjalankan tugasnya dengan satu motto dan semboyan, yaitu "building for the excellent."

Kriteria Unggul pertama tentu harus diterapkan untuk para guru yang bertugas di sekolah, dari mulai guru Matematika, guru Bahasa, guru IPA, guru IPS, guru Kesenian, hingga Guru Pendidikan Jasmani. Mereka ini harus mampu menjalankan misi sekolah yang bertugas mencetak atlet juara, yang dilandasi oleh visi yang ideal untuk sekolah tersebut. Para guru inipun didukung oleh sekelompok guru yang bertugas untuk memberikan semacam program remedial atau pembelajaran tambahan bagi peserta didik yang sedang difokuskan untuk menghadapi kejuaraan khusus.

Kriteria Unggul kedua, dan ini yang akhirnya menjadi penentu kualitas Kelas Olahraga ini, yaitu kualitas para pelatih yang direkrut untuk setiap cabang olahraga. Pelatih setiap cabor harus merupakan tim yang terbaik dari yang ada, sehingga mencerminkan layanan kualitas pelatihan dan pembinaan yang unggul pula. Jika perlu tim pelatih ini didukung oleh tim konsultan (misalnya melibatkan dosen-dosen FIK/FPOK) yang bertugas mengendalikan program dan seluruh proses latihan serta pemantauan dan evaluasinya, sehingga memberikan jaminan penuh pada hasilnya yang terbaik tersebut. Bahkan, untuk kepentingan continous improvement, para pelatih sekolah ini didukung dalam hal peningkatan kompetensinya melalui keikutsertan mereka dalam berbagai macam lokakarya atau pelatihan/penataran.

\section{Life Skill Center}

Lebih penting dari semuanya, Kelas Olahraga inipun harus sekaligus menjadi LifeSkill Center, yang di samping mempersiapkan atlet yang berhasil dari sisi prestasinya, juga sekaligus mempersiapkan anak sebagai manusia yang berhasil dalam karir di luar karir keatletannya. Artinya, para siswa anggota Kelas Olahraga ini diarahkan untuk memiliki keterampilan hidup yang diperlukan kelak untuk berhasil dalam menempuh hidupnya.

\section{PENGEMBANGAN KELAS OLAHRAGA}

Dari sisi program, hendaknya kelas olahraga ini dapat mengadopsi kurikulum yang dikembangkan federasi cabor yang dipilih. Kurikulum tersebut biasanya membagi para atlet dalam beberapa kelompok berdasarkan usia atau berdasarkan kemampuannya. Dengan demikian, program kelas olahraga tidak menyatukan siswa/atlet dari kelas IX dengan siswa dari kelas VIII atau VII dalam pelaksanaan latihannya. Sejauh mungkin, mereka harus mengikuti program latihan yang sesuai dengan level-nya. Dengan demikian, para siswa secara jelas terpetakan posisinya, apakah ia masuk level pemula, level lanjutan, atau level mahir. Bahkan untuk olahraga tertentu, misalnya pada cabor senam, level-level tersebut diperinci lagi misalnya dengan mengelompokkan pelevelan ini pada peringkat yang lebih detil: pemula dibagi ke dalam tiga level (level 1, level 2, dan level 3), level lanjutan dibagi ke dalam 3 level (level 4, level 5, dan level 6), kemudian level lanjutan juga dibagi ke dalam 3 level, yaitu level 7, level 8, dan level 9. Sedangkan di atas itu semua, level 10 mewakili tingkat senior.

Dengan sistem semacam itu, yang mana setiap level menunjukkan tingkat penguasaan keterampilan tertentu yang juga sudah ditentukan, akan cukup jelas kapan siswa dapat meningkat atau memperbaiki levelnya ke level berikut, serta persyaratan kompetensi apa yang harus dilewatinya melalui sebuah mekanisme 
ujian kenaikan tingkat atau melalui kejuaraan. Di samping itu, cukup jelas juga kewenangan pelatih dan penguji (wasit), yang untuk mampu menjalankan fungsinya pada level tertentu pun harus pula memiliki peringkat tertentu, apakah ia pelatih atau wasit pemula, pelatih atau wasit lanjutan, atau termasuk pelatih atau wasit tingkat mahir (nasional) dan bahkan tingkat internasional.

\section{PROGRAM KOMPETISI}

Tidak kalah pentingnya dari program Kelas Olahraga di atas adalah (menciptakan) sistem kompetisi yang teratur dan tersistem. Kompetisi merupakan sebuah kewajiban bagi sekolah, untuk minimal menyelenggarakan kompetisi antar kelas di lingkungan sekolah tersebut, atau lajim di sebut program intramural. Bahkan kalau mungkin sekolah yang bersangkutan mampu (menciptakan) menyelenggarakan program kompetisi ekstramular (antar sekolah) dengan bekerja sama dengan sekolah penyelenggara Kelas olahraga lainnya.

Jika pun di kota tertentu tidak tersedia sekolah yang memiliki Kelas Olahraga lain, pelaksanaan kompetisi dengan Sekolah nonKelas Olahraga pun tetap akan memberikan dampak positif lainnya. Sifat kompetisi dirancang dalam format yang sangat sederhana, sehingga tidak perlu mengeluarkan biaya tinggi, tetapi mampu membangkitkan nilai kebanggaan pada para pesertanya, serta yang paling penting adalah dimanfaatkannya kompetisi itu sebagai ajang untuk membina nilai dan sifat-sifat luhur keolahragaan bagi para peserta. Dengan demikian, siswa mampu menyelami dan menginternalisasi nilai-nilai sportivitas, fair play, kejujuran, semangat pantang menyerah, menghargai keunggulan diri sendiri dan lawan, serta membina semangat kerja sama, korp, serta menjunjung sikap hormat pada orang lain.

\section{Kompetisi Antar Kelas}

Dalam konteks pembinaan jiwa bertanding dan pengembangan nilai-nilai sportivitas, di sekolah dengan program Kelas Olahraga, perlu juga dikembangkan apa yang disebut Kompetisi
Antar Kelas. Namun dalam kaitan ini, kompetisi ini bukan hanya mempertandingkan kelas-kelas olahraga yang ada, tetapi juga melibatkan kelas yang non-olahraga. Bagi siswa dari Kelas Olahraga, kompetisi semacam ini diperlukan untuk membangkitkan rasa kebanggaan mereka, agar secara luas, mereka dikenal sebagai anggota kelas olahraga yang ada di sekolah itu. Sedangkan bagi siswa yang non-kelas olahraga, keterlibatan merea akan menjadi semacam, pendorong semangat untuk berkenalan dan mengetahui keberhasilan program kelas olaharag di sekolah mereka.

Kompetisi antar kelas sebenarnya merupakan bentuk kejuaraan yang sudah dikenal luas di sekolah. Namun dengan kecenderungan semakin padatnya agenda sekolah dan semakin berkurangnya perhatian sekolah pada program olahraga dan termasuk terbatasnya ketersediaan alat di sekolah, maka dewasa ini banyak sekolah yang menghilangkan agenda pertandingan ini dari agenda sekolah. Bahkan, ada juga pihak sekolah yang mengemukakan alasan, dihilangkannya pertandingan ini karena adanya kekhawatiran timbulnya reaksi serta dampak negatif dari peristiwa pertandingan olahraga yang sering mengarah pada tawuran antar siswa. Itulah jika kejuaraan lebih ditekankan pada "pertandingan."

Pada masa-masa awal dulu, agenda pertandingan antar kelas sudah ditradisikan sebagai agenda penutup kegiatan akademik di akhir semester. Formatnya adalah bahwa sekolah melalui panitia yang dibentuk, menyelenggarakan pertandingan antar kelas dengan memilih cabor-cabor yang popular di kalangan anak sekolah, seperti basket, voli dan sepak bola.

Dengan format seperti itu, setiap kelas diminta untuk membentuk tim kelasnya masingmasing, dan pada jadwal yang ditetapkan, dilaksanakan pertandingan, yang biasanya memakan waktu sekitar 3 hingga 5 hari berturutturut, tergantung dari system pertandingan yang ditetapkan, entah dengan system gugur atau system setengah kompetisi. 
Untuk kepentingan menghidupkan kembali tradisi pertandingan antar kelas, memang pihak sekolah harus cukup berhati-hati mempertimbangkan berbagai kemungkinannya. Salah satu di antaranya yaitu harus mengeliminir kecenderungan siswa dalam bereaksi negatif terhadap hasil pertandingan.

Untuk itu, pertandingan antar kelas di sekolah, jika memungkinkan, perlu digelar dengan memasukkan sifat-sifat festival ke dalamnya, seperti menetapkan kategori kelas yang berhasil tidak hanya dari hasil akhir pertandingan yang menjadi juara, tetapi perlu juga dicari kategori-kategori unggulan lain, seperti kelas ter-sportif, kelas terpavorit, kelas paling disiplin, kelas dengan supporter tersopan, dsb.

Kemudian, untuk tidak terlalu mengundang efek negative dari pertandingan, perlu juga kejuaraan antara kelas di sekolah memasukkan unsur lomba yang sifatnya massal, tetapi tidak memperhadapkan siswa dalam kontak fisik langsung. Lomba yang cocok dimasukkan adalah lomba senam massal sehingga makin banyak siswa yang terlibat.

\section{Kompetisi Antar Sekolah}

Kompetisi antar sekolah sebenarnya merupakan perluasan dari kompetisi antar kelas yang terjadi di lingkungan sekolah masingmasing. Panitia untuk kompetisi antar sekolah ini adalah hendaknya dibentuk oleh disdik kota/kabupaten dibantu oleh guru-guru penjas dari setiap sekolah. Tetapi jika memungkinkan, kompetisi antar sekolah ini dibatasi hanya untuk setiap kecamatan terlebih dahulu.

Karena jumlah SMP di satu kecamatan biasanya tidak terlalu banyak, maka kompetisi antar sekolah benar-benar melibatkan semua sekolah yang ada di lingkungan kecamatan tersebut.

Adapun jenis kompetisi dan jumlah cabor yang diprogramkan tentu perlu dipertimbangkan dengan melihat jumlah sekolah yang ada (tentu berbeda-beda jumlahnya antar kecamatan), sehingga agenda dan waktu yang tersedia dapat disesuaikan.

\section{MANAJEMEN KELAS OLAHRAGA}

Kelas olahraga tentu harus menjalankan pengelolaan programnya sesuai dengan manajemen olahraga modern, dengan menekankan aspek transparansi dan keterbukaan dalam hal program, keuangan, serta pelaksanaan pelatihannya. Termasuk dalam perekrutan pelatih, sekolah dapat melakukan intervensi dalam hal apakah pelatih yang direkrut dan ditugaskan memiliki kemampuan melatih dan mendidik anak, juga dalam hal kelengkapan formal kompetensinya, seperti sertifikat dan brevet yang menyatakan dirinya memiliki kualifikasi tertentu.

Kepada pengurus Kelas Olahraga, sekolah harus menuntut agar pengurus mampu melaksanakan program kenaikan peringkat dan kejuaraan antar kelas dengan sistem perlombaan atau pertandingan yang dapat dipertanggung jawabkan, dari mulai penatalaksanaan kejuaraan dan kebenaran proses kenaikan peringkat setiap siswa. Siswa yang dipandang menonjol, kemudian dipersiapkan pula untuk menghadapi program kejuaraan atau pertandingan antarsekolah. Program ini dapat dilaksanakan atas kerja sama antara sekolah kelas olahraga sejenis dari beberapa sekolah, yang pelaksanaannya melibatkan bantuan dan koordinasi dari induk organisasi olahraga yang bersangkutan di lingkungan tugasnya (seperti Pengcab atau Pengda). Kerjasama ini diperlukan, terutama untuk mendapat bantuan teknis dalam hal ketatalaksanaan pertandingan dan perwasitan.

Selanjutnya, dengan masih memanfaatkan kerjasama dengan induk organisasi yang memayungi cabang olahraga yang dikembangkannya, setiap klub juga harus mampu melakukan pemantauan secara berkala untuk memilih siswa yang benar-benar berbakat, terutama dengan memanfaatkan pelaksanaan program Antar Kelas dan Antar-Sekolah. Siswa yang dipandang berbakat, diusulkan dan dilaporkan kepada pusat pelatihan olahraga wilayah atau nasional (Pelatda atau Pelatnas) untuk memndapatkan pemantauan lebih lanjut. Siswa yang diterima pada program Pelatda atau Pelatnas akan menjalani program itu secara 
berbeda, dan yang harus dipertimbangkan adalah mendukung kepindahan siswa tersebut agar terjamin kelanjutan sekolahnya serta status keatletan dari sisi domisilinya.

\section{PRASYARAT PELAKSANAAN KELAS OLAHRAGA}

Pelaksanaan program Kelas Olahraga dengan model yang telah dikemukakan di atas dapat berlangsung dengan baik jika ditunjang oleh beberapa prakondisi atau prasyarat sebagai berikut:

\section{Pelatih}

Pelaksanaan program Kelas Olahraga yang baik mempersyaratkan hadirnya para pelatih yang memiliki wawasan kependidikan, bisnis, serta manajemen yang luas di samping perlu memiliki kemampuan mengatur dan mengorganisasikan proses pelatihan secara memadai. Pelatih ini bisa dihasilkan oleh institusi resmi seperti FPOK atau FIK, atau dapat juga merupakan produk dari sistem pendidikan dan pelatihan yang dilaksanakan oleh induk-induk organisasi. Dalam hal ini, baik lembaga kependidikan maupun induk organisasi harus mencoba merumuskan sistem pendidikan pelatih secara serius, bahkan harus merupakan program bersama. Pelatih dididik secara sistematis, dengan dibekali pengetahuan dan keterampilan yang berkaitan dengan pelatihan cabang olahraga yang ditekuninya serta beberapa ilmu pengetahuan pendukung, serta tidak kalah pentingnya termasuk ilmu-ilmu yang berkaitan dengan pedagogi olahraga, sehingga mereka mampu memainkan peranannya baik sebagai pelatih maupun sebagai pendidik.

Bahkan untuk memperkokoh program ini secara keseluruhan, program pendidikan jasmani dalam pelajaran sekolahpun perlu diperbaiki dengan meningkatkan kesadaran dan kemampuan para guru penjas berkaitan dengan tugasnya. Dua hal yang perlu ditekankan dalam memperbaiki kualitas guru penjas ini, yaitu pertama, perlu dikuasainya model-model kurikulum pendidikan jasmani secara komprehensif, sehingga para guru memiliki keyakinan kuat tentang orientasi atau arah dari pengajarannya. Kedua, para guru penjas pun perlu ditingkatkan keterampilan pengajarannya, sehingga mampu memimpin kelas pendidikan jasmaninya secara menarik, mencapai sasaran, dan bermakna bagi perkembangan fisik, motorik, mental, emosional serta sosial anak.

\section{Program atau kurikulum,}

Setiap kelas olahraga sekolah hendaknya mampu melaksanakan programnya masingmasing secara tersistem, sehingga kemajuan pembelajaran dan hasil pelatihan yang dilakoni oleh siswa mampu berlangsung secara progresif sesuai dengan tahapan dari kelompok atau keluarga keterampilan yang diperlukan. Untuk itu, setiap klub dan pusat olahraga harus memiliki kurikulum dan program yang jelas bagi setiap kelompok atau peringkat siswa peserta, sehingga antara satu siswa baru dengan siswa yang sudah menjalani programnya ada perbedaan perlakuan. Dengan kurikulum itupun, akan dapat diketahui adanya perbedaan peringkat antara satu anak dengan anak lainnya, sehingga memudahkan tugas pelatih dalam menentukan tingkat kesulitan tugas gerak dan porsi latihannya.

Untuk mendukung ke arah itu, bagi kelas olahraga yang induk organisasi cabornya sudah menyediakan sistem pengembangannya, dapat langsung mengadopsi sistem itu sebagai kurikulum bakunya. Bagi cabang olahraga yang kebetulan belum memiliki sistem, maka diperlukan upaya bersama dari para pelatih yang tergabung dalam cabang olahraga yang sama untuk bersama-sama merumuskan kurikulum atau sistem yang diperlukan. Sistem ini sungguh-sungguh diperlukan untuk menjaga kualitas dan keberlangsungan program, sehingga tidak seperti tumbuhnya jamur di musim penghujan. Cepat tumbuh dan berkembang, tetapi hanya bertahan pada musim tertentu saja.

\section{Fasilitas sekolah}

Pelaksanaan program kelas olahraga di sekolah pada dasarnya merupakan proses belajar 
yang berlangsung di sekolah atau di lingkungan sekolah, yang karenanya tentulah banyak memanfaatkan fasilitas olahraga yang ada di sekolah. Tergantung fasilitas apa yang tersedia di sekolah, tentu cabor yang dipilih pun sesuai dengan keberadaan fasilitas tersebut.

Lambat laun, ketika kelas olahraga sudah berjalan baik, maka diharapkan pengurus yang bersangkutan pun dapat menambah kelengkapan alat bagi sekolah. Kehadiran perlengkapan tersebut bukan saja menunjang bagi pelaksanaan kelas olahraga, tetapi juga menunjang bagi berlangsungnya program Penjas dan olahraga di sekolah yang bersangkutan. Ingat, seharusnya, sekolah yang memiliki program Kelas Olahraga, seharusnya sekaligus memiliki program Penjas dan Ekstrakurikuler bagi siswa umunya yang lebih baik dari sekolah-sekolah lainnya.

Jika pelaksanaan Kelas Olahraga di sekolah tidak dapat dilaksanakan karena dukungan infrastruktur keolahragaan yang diharapkan tidak memadai, maka kelas olahraga hendaknya dapat dilaksanakan dengan bekerja sama dengan sekolah atau lembaga lain yang peralatannya dipandang paling memadai.

\section{Pendanaan}

Pembiayaan program kelas olahraga idealnya dapat didukung oleh dana APBD setiap kota atau kabupaten melalui dinas pendidikannya, yang dikelola secara resmi. Dana ini diperlukan bagi perumusan program, pembayaran honor pelatih, honor pengelola, dan jika mungkin meng-cover pula pembiayaan penambahan peralatan. Apakah para siswa yang menjadi peserta kelas olahraga perlu ditanggung biaya kehidupannya? Itu tergantung kebijakan dan kemampuan daerah. Jika tidak pun, justru diharapkan orang tua para peserta masih bersedia dan mampu mengulurkan bantuan bagi kepentingan kemajuan anak-anaknya. Kalu memungkinkan, mereka mendapat dukungan dari bea-siswa pemerintah.

\section{Infrastruktur.}

Infrastruktur lain tetap diperlukan. Kesemua itu meliputi misalnya tersedianya lapangan, gedung olahraga, stadion, hingga taman-taman kota yang dapat dimanfaatkan. Di samping itu tentu diperlukan pula peralatan utama seperti bola, matras, peluru, atau alat-alat pelindung badan. Jika mungkin, kebutuhan untuk penyediaan dan pembangunan infrastruktur ini dipenuhi oleh pemerintah daerah kota atau kabupaten, melalui dinas atau sub-dinas yang terkait. Mudah-mudahan program kelas olahraga ini dapat membuka simpul kejumudan berfikir dari berbagai pimpinan lembaga/dinas yang selama ini sering terjadi.

\section{PENUTUP}

Demikianlah pokok-pokok pikiran yang tertuang dalam naskah ini, yang diharapkan dapat memberikan inspirasi bagi lahirnya pandangan dan pikiran lebih lanjut dalam mewujudkan dan merealisasikan program Kelas Olahraga di bawah sub-sistem persekolahan. Pikiran-pikiran strategis lainnya masih perlu dilahirkan berkaitan dengan tahapan implementasi yang konkrit untuk menterjadikan didirikannya sekolah tersebut dari tahapan yang tadinya hanya berupa wacana hingga tahapan sekolah itu dapat terselenggara dengan kemampuan memenuhi seluruh kriteria dasarnya.

Mudah-mudahan bahan pemikiran ini mendapat sambutan dan dukungan dari semua pihak, termasuk dalam upaya melengkapi bahan yang sederhana ini, sehingga akhirnya program Kelas Olahraga ini dapat terealisasi dan memberikan kontribusi nyata pada peningkatan prestasi olahraga nasional. Semoga.. 


\section{DAFTAR PUSTAKA}

UU No 3 Tahun 2005. UU Sistem Keolahragaan Nasional. Kemenpora RI.

PP no 16, 17 dan 18 tahun 2007. Kemenpora RI.

Heinemann, Klaus (Ed.) (2003) Sport and Welfare Policies: Six European Case Studies. Cologne, Germany: Verlag Karl Hofmann.

Hylton, Kevin., Bramham, Peter. (2010). Sport Development: Policy, Process and Practice. London and New York: Routledge Taylor \& Francis Group.

Nugroho, Riant. (2006) Kebijakan Publik Untuk Negara-Negara Berkembang. Model-model Perumusan, Implementasi dan Evaluasi. Jakarta: Gramedia.

Health Canada (1998), Improving the Health of Canadians throgh Active Living, Ottawa.

Hylton, Kevin., Bramham, Peter., (2010). Sports Development: Policy, Process and Parctice. London and New York: Routledge Taylor \& Francis Group. 